\title{
O423 Risk of new AIDS-defining events in patients with advanced immunodeficiency during suppressive HAART: results from the German ClinSurv cohort
}

\author{
A Zoufaly*1, C Kreuzberg11, M An der Heiden², C Kollan², O Hamouda² and \\ J van Lunzen ${ }^{1}$
}

Address: ${ }^{1}$ University Medical Center Hamburg-Eppendorf, Hamburg, Germany and ${ }^{2}$ Robert Koch Institute, Berlin, Germany

* Corresponding author

from Ninth International Congress on Drug Therapy in HIV Infection

Glasgow, UK. 9-13 November 2008

Published: 10 November 2008

Journal of the International AIDS Society 2008, I I (Suppl I):O45 doi:I0.1 I86/I758-2652-II-SI-O45

This abstract is available from: http://www.jiasociety.org/content/I I/SI/O45

(c) 2008 Zoufaly et al; licensee BioMed Central Ltd.

\section{Purpose of the study}

Despite recent advances in the reduction of morbidity and mortality after the advent of HAART, a large number of HIV patients still present late with advanced immunodeficiency. In these patients the risk of developing AIDSdefining events (ADE) may depend on a solid immune reconstitution with immune-discordant responses being at higher risk. We aimed to determine risk factors for the development of ADE in patients who begin fully suppressive antiretroviral treatment with CD4 counts $<200$ cells/ $\mu \mathrm{l}$.

\section{Methods}

Data of 1,576 treatment-naive patients starting HAART after January 1, 1996 at a CD4 count $<200$ cells/ $\mu$ l were followed from the date of full viral suppression until virological failure, the occurrence of a new ADE, loss of follow-up or December 31, 2007, whichever occurred first. An adjusted Poisson regression model was used to analyze the incidence rate ratio (IRR) between immune-discordance (all CD4 counts $<200$ cells $/ \mu$ l) and immuneresponse (at least one CD4 count $>200$ cells $/ \mu \mathrm{l}$ ) in the first, second, and third year. In addition, a Cox model was fitted to analyze risk factors for a new ADE encompassing all available follow-up data.

\section{Results}

In the first year a total of 42 new ADE occurred with an IRR for immune-discordance of $5.57 \quad(95 \%$ CI
2.96-10.48, $\mathrm{p}<0.001)$ in the adjusted Poisson model. In the second (nine events) and third year (eight events) of viral control, a non-significant trend towards a lower influence of immune-discordance was observed (IRR $1.03,95 \%$ CI $0.13-8.26, \mathrm{p}=0.98$ and $2.02,95 \%$ CI $0.25-16.41, p=0.51$, respectively). In the Cox model analyzing 3,633 person-years of follow-up, risk factors for development of a new ADE included the latest CD4 count below 50 cells $/ \mu$ l (HR 6.36,95\% CI 2.53-15.95, p < 0.001 ) and CD4 counts between 50-100 cells/ $\mu$ (HR $3.84,95 \%$ CI $1.70-8.68, \mathrm{p}=0.001$ ). No significant influence of latest CD4 count above 100 cells/ $\mu \mathrm{l}, \mathrm{CD} 4$ count at initiation of HAART, sex, age, transmission risk, and AIDS-defining event prior to initiation of HAART was observed.

\section{Conclusion}

Immune-discordance is a risk factor for a new ADE while on HAART during the first year of suppressed viremia. After this time the incidence of ADE decreases dramatically even in patients with prolonged immunodeficiency. The risk is highest in patients who fail to increase CD4 counts to $>100$ cells $/ \mu$ l. Strategies to raise or maintain a CD 4 count above at least 100 cells/ $\mu$ l could prevent most $\mathrm{ADE}$ in this patient group. See Figure 1. 


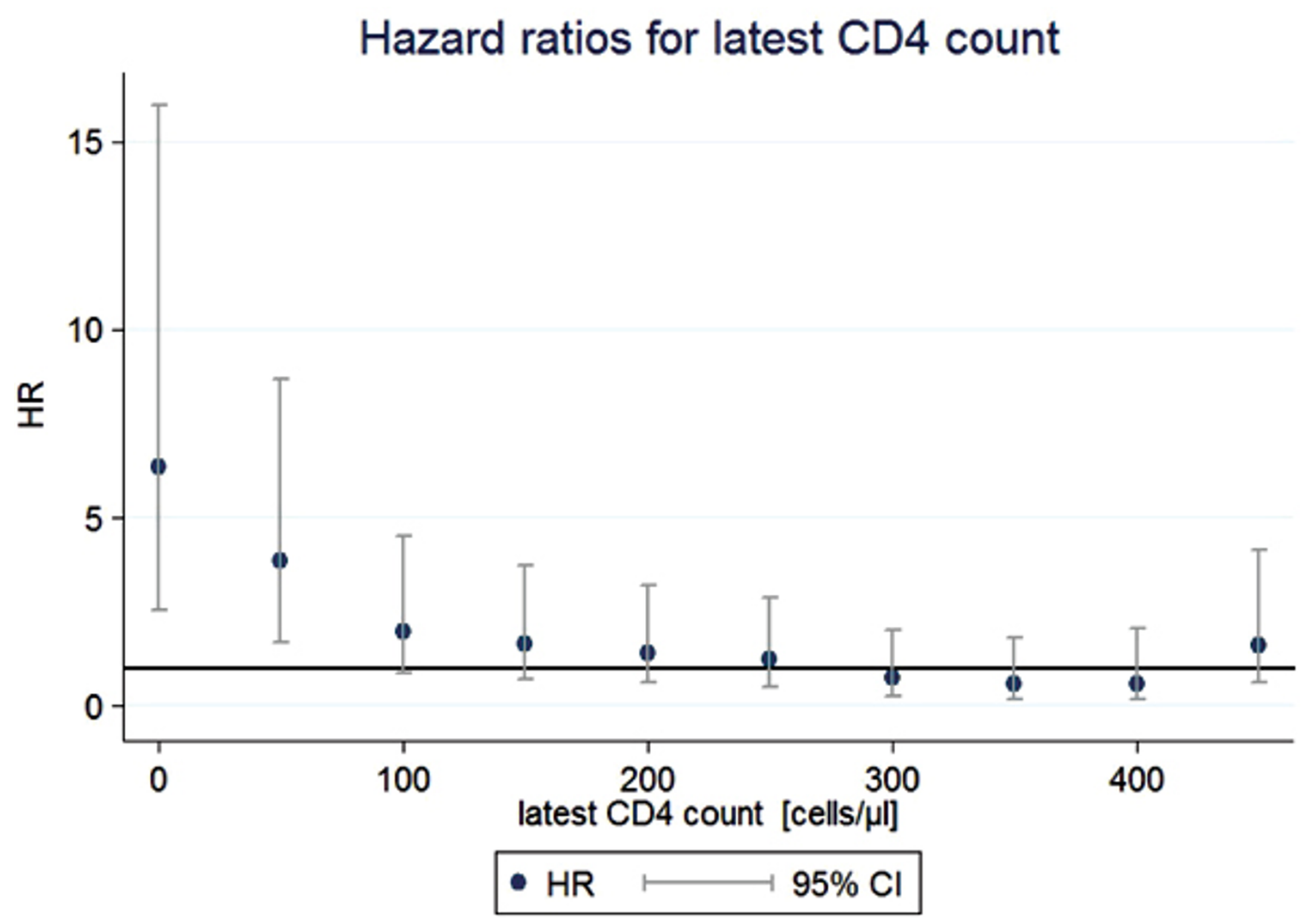

Figure I

Hazard ratios for latest CD4 count.

Publish with Biomed Central and every scientist can read your work free of charge

"BioMed Central will be the most significant development for disseminating the results of biomedical research in our lifetime. "

Sir Paul Nurse, Cancer Research UK

Your research papers will be:

- available free of charge to the entire biomedical community

- peer reviewed and published immediately upon acceptance

- cited in PubMed and archived on PubMed Central

- yours - you keep the copyright
BioMedcentral 